\title{
Examining the Relationship Between PsyCap and Readiness for Change: Implementation of E-learning Among Lecturers During Covid-19
}

\author{
Endo Wijaya Kartika ${ }^{a}$, Zeplin Jiwa Husada Tarigan ${ }^{b}$, Adrie Oktavio \\ assistant Professor, Faculty of Business and Economics, Petra Christian \\ University, Indonesia, ${ }^{\mathrm{b}}$ Associate Professor, Faculty of Business and \\ Economics, Petra Christian University, Indonesia, ${ }^{\mathrm{c}}$ Assistant Professor, Faculty \\ of Tourism, Universitas Ciputra Surabaya, Indonesia, Email: aendo@petra.ac.id
}

\begin{abstract}
The impact of the Covid-19 disease pandemic caused the official government ministry of education in Indonesia to take a strategic step, conducting teaching by e-learning. In the university context, for lecturers who are technologically illiterate, the use of e-learning could be a burden and difficult to learn quickly. It required a readiness for change to adapt and learn e-learning. An antecedent that is considered to shape readiness for change from an individual perspective is Psychological Capital (PsyCap). Therefore, this study, in addition to understanding the readiness for change based on PsyCap by Indonesian lecturers, also provides empirical evidence of the PsyCap dimensions of readiness for change. The data process was conducted using SmartPLS 2.0. The results indicate that selfefficacy, optimism and resilience have significant effects on readiness for change, while hope has no significant effect on readiness for change.
\end{abstract}

Key words: PsyCap, Readiness for Change, Lecturers, e-Learning, Covid-19

\section{INTRODUCTION}

Since the beginning of 2020, almost all countries in the world are now busy with the alarming situation and condition of the Coronavirus (Covid-19) disease pandemic. According to data reported by WHO (2020), up until mid-April 2020 the number of people positively exposed to the Covid-19 disease reached more than 2.4 million people, with 170,000 deaths worldwide. The number is certain to continue growing, considering that the handling of the disease is still continuing. The Covid-19 pandemic has dealt a blow to all sectors, including the education 
sector, which has forced students to learn from home by attending online learning facilitated by their education institution (Alhefnawi et al, 2021). The long-term impact has the potential to impede the process of development and maturity of students, especially in the future (AlRabiaah et al, 2020).

In Indonesia, the impact of the increasingly massive spread of Covid-19 has made the official government ministry in education take a strategic step by circulating a letter about the implementation of education in case of an emergency period of Covid-19 (Ministry of Education and Culture of the Republic of Indonesia, 2020). One of its contents stated the replacement of the educational process from regular face-to-face learning into online learning. This kind of education process will cover all levels of education ranging from elementary school to higher education such as university. For higher education, this kind of policy creates a dilemma - on the one hand, many lecturers and students are very enthusiastic about the change in learning methods, on the other hand, many kinds of preparation and adaptation are required by both lecturers and students to be able to keep up with those changes. Some universities have started preparing online learning plans for their students, but still many problems come up beyond their understanding, even though online learning is not a new learning model for most universities in Indonesia (Berliyanto \& Santoso, 2018). However, in previous years, it has been an innovation that supported universities' excellence and demonstrated their advancement, as well as anticipation, toward changes that might happen in the future (Pachura, 2017). Many academics, including lectures and students, have received training to handle online learning platforms to be used either as the primary learning method or in addition to the regular face-to-face learning method (Mutia \& Leonard, 2015). However, it cannot be denied that there are still some universities that are not ready and do not have sufficient resources to apply the online learning model (e-learning system).

The transition to the e-learning model has raised questions for some universities about their ability to deal with existing technology (Lee, 2020). In the midst of the situation of the spread of Covid-19, which forced academic communities to work or learn from home, educators or lecturers have had to have adequate technology infrastructure and internet networks to guarantee the smooth running of their tasks. From the students' perspective, not all students have adequate access to the internet in their respective homes. In addition, practical classes also have different constraints and difficulties when conducted online (Alhefnawi et al, 2021). Reflecting on these constraints and difficulties, it could be concluded that the quality of elearning education is one of the prominent issue that requires serious solving (Kebritchi, Lipschuetz, \& Santiague, 2017; Sun \& Chen, 2016).

The Covid-19 pandemic is a severe health crisis in the $21^{\text {st }}$ century. This pandemic also causes severe short-term disorders that are felt by many families. Home learning activities could disrupt parents' productivity. Social life is also disrupted and personal learning disorders could develop. Learning has to be moved to a scale that has not been tested in a massive context, nor has this ever happened before. Student assessments are also conducted online with lots of trial 
and error and also uncertain results for everyone. Many assessments have also compensated for, or even cancelled due to adaptation to, the new online system. Therefore, these kinds of disorders may not only be in short-term problems, but could also developed into long-term problems and consequences for those who are affected, and this also tends to increase inequality (Sahu, 2020).

Principally, the application of e-learning is one of the efforts or strategies to continue the learning and education process as it should proceed (Sun \& Chen, 2016; Hafeez et al, 2021). However, if e-learning is not accompanied by sufficient capabilities and additional knowledge for its users, it can definitely cause serious problems (Darling-Hammond, Flook, Cook-Harvey, Barron, \& Osher, 2020). For example, as stated by Perbawaningsih (2013) and Crossley and McNamara (2016) an online system could provide benefits and challenges for lecturers who are classified as technologically illiterate, relating to the use of an online learning platform that was provided by their universities. For lecturers who are technologically illiterate, the use of e-learning will be a burden and difficult to follow and learn quickly (Islam, Beer, \& Slack, 2015). At the present time, the term technologically illiterate is not about the lack of understanding, but more about knowing how to use it yet with less understanding about the real function and its benefit (Mishra \& Koehler, 2006). When a lecturer is introduced to e-learning from the institution, sufficient time is required to learn everything to support the learning and teaching process with students (Hafeez et al, 2021). Therefore, a readiness is required by the lecturer to change the learning concept and method into an online one (Ahmad, Yoke, Yunos, \& Amin, 2019).

Readiness for change is the thought of an individual within an organisation about a change that is considered to have positive impact and provide a good thing for the individual and the organisation (Kirrane, Lennon, O'Connor, \& Fu, 2017; Surjantia et al, 2020)). Readiness for change can have a positive effect on an individual basis. When members of the organisation have a high degree of readiness for change, they will be more likely to demonstrate change initiatives; increased support for change; take prosocial actions such as helping other members of the organisation in making changes; and have a higher commitment (Shea, Jacobs, Esserman, Bruce, \& Weiner, 2014; Weiner, 2009).

An antecedent that is considered important for shaping readiness for change from an individual perspective is Psychological Capital (PsyCap). PsyCap can be defined as a condition of the psychological development of individual who has positive thought through several indications of important characteristics, such as self-confidence; thinking positive for success; having the determination to achieve goals successfully; and having a high "fighting spirit" to get through "ups and downs" in order to achieve success (Luthans, Youssef, \& Avolio, 2007; YoussefMorgan \& Luthans, 2015). Several studies have been conducted, and empirically proven, that PsyCap that is owned individually can increase the readiness of the individual to change (Avey, Wernsing, \& Luthans, 2008; Kirrane et al., 2017; Lizar, Mangundjaya, \& Rachmawan, 2015). 
However, only a few studies have been conducted partially on the impact affected from each of PsyCap's dimensions (including self-efficacy, optimism, hope and resilience to readiness for change). Exceptions include the studies by Nwanzu and Babalola (2019) that use the dimensions self-efficacy, optimism and resilience as the antecedents of individual attitudes towards change in organisations, and Sweetman, Luthans, Avey and Luthans (2011), who use the dimensions in their relation to creativity.

In the developing study of PsyCap, several studies have been conducted in Indonesia in several different contexts, including its role to improve performance (Liwarto \& Kurniawan, 2015; Widianto \& Wilderom, 2017); work engagement (Nugroho, Mujiasih, \& Prihatsanti, 2013); and readiness for change (Fachruddin \& Mangundjaya, 20120; Lizar et al., 2015). However, the previous studies use PsyCap as a unidimensional construct rather than as a multidimensional. Therefore, this study is an addition to understanding the readiness for change based on the PsyCap owned by universities' lecturers in East Java, Indonesia. It also serves to provide empirical evidence of the PsyCap dimensions, which include self-efficacy, optimism, hope, and resilience, in their role in making an impact on readiness for change.

\section{REVIEW OF LITERATURE}

\section{Psychological Capital (PsyCap)}

The development of the PsyCap concept has increased due to the need to learn and develop positive human characteristics as a self-potential to grow better (Çavuş \& Gökçen, 2015). The interest in learning these characteristics is growing rapidly, especially in an organisational behaviour context (Luthans \& Avolio, 2009). The basis for this concept refers to Fredrickson's (2001) thought about the "broaden and build" theory, whereas the experience of an individual's positive emotions could expand individua cognitive understanding which then has a positive impact, with outcomes such as creative thinking, better personal development and increased compentencies. This theoretical approach then becomes the rationale for the application of PsyCap, where an individual's psychological conditions could encourage positive thinking and also proactively develop psychological capacity for positive thought (Kirrane et al., 2017).

PsyCap can be defined as a condition of the psychological development of an individual who has positive thought, through several indications of important characteristics, such as selfefficacy, optimism, hope and resilience (Luthans, Youssef-Morgan, \& Avolio, 2015; Luthans et al., 2007). Self-efficacy (or what can simply be called self-confidence), is a sense of trust in an individual's ability to unite the motivation, knowledge and action needed to achieve the desired goals (Luthans et al., 2015); optimism can be interpreted as an individual's feeling of trust that the individual will experience more positive things than negative things from all action taken (Nwanzu \& Babalola, 2019); while hope is a condition of positive motivation that comes from a strong will to set realistic goals and at the same time find out how to achieve 
success (Luthans et al., 2015); and finally, resilience is the positive psychic ability of individuals toward their efforts to rise again from difficulties, uncertainties, conflicts or even failures, during their process of achieving goals (Sweetman et al., 2011).

\section{Readiness for change}

Change is a continuous part of basic human life, and also considered one of the important factors in the knowledge development within organisational theory. It emphasises the study thoroughly from macro and micro perspectives related to individual change behaviour in organisations (Surjantia et al, 2020). According to Kirrane et al. (2017), readiness for change can be defined as the thoughts of an individual within an organisation, related to a change that is considered to have positive outcomes and is also a good thing for the individual and organisation. As a construct, readiness for change can be at the individual level, and up to the organisation level (Vakola, 2013; Vakola, 2014). Hence, in general it refers to the readiness to commit to implementing changes at any level to achieve organisational goals in general (Weiner, 2009).

The elaboration concept in the context of readiness for change refers to Bouckenooge, Devos and Van Den Broeck (2009) who explain the three elements that shape an individual's readiness for change, namely emotional, cognitive and intentional. The emotional element refers to the individual's feelings about the changes that may be faced; the cognitive element leads to individual thought and belief in the results that can be obtain from these changes; and the intentional element refers to the efforts and abilities of individual to carry out the process of change (Bouckenooghe et al., 2009; Kirrane et al., 2017).

\section{Self-efficacy and readiness for change}

Luthans et al. (2015) state that self-efficacy is defined as trust in the ability of an individual to gather the motivation, knowledge and action required to achieve desired goals. In this case efficacy is related to the individual's perception of the ability possessed to perform a task (Gangloff \& Mazilescu, 2017). When an individual has high self-efficacy that is able to undergo changes, the more prepared the individual is to make changes. Self-confidence can influence the perception of feeling confident enough to successfully make changes and get the results that are wanted through the changes (Nwanzu \& Babalola, 2019). Empirically, the result from Emsza, Eliyana and Istyarini (2016), and also that from Nwanzu and Babalola (2019), proves that self-efficacy has a significant effect on readiness for change.

$\mathrm{H}_{1}$ : self-efficacy has a significant effect on readiness for change. 


\section{Optimism and readiness for change}

Optimism is an individual's perception related to the belief that the individual will experience positive things more than negative things (Luthans et al., 2015). Optimistic individuals tend not to experience stress quickly, especially during facing difficulties compared to pessimistic individuals (Aspinwall, Richter, \& Hoffman, 2004; Peterson De Avila, 1995). Hence, when the individual is confronted with a change process that must be gone through, the individual tends to have the confidence required to be able to successfully navigate the change process, regarding the difficulties. Such individuals will also tend to cope better with the stress caused, and also tends to be more prepared for changes (Nwanzu \& Babalola, 2019). The result of the previous empirical studies show that optimism significantly affects readiness for change (Nwanzu \& Babalola, 2019; Wanberg \& Banas, 2000).

H2: optimism has a significant effect on readiness for change.

\section{Hope and readiness for change}

Hope is a belief determining the goals to be significantly achieved (Çetin, 2011). Hope is a state of mind that is based on the interactive feeling of two beliefs namely agency thinking and pathway thinking, regarding of how personal goals can be achieved (agency thinking) and the planning path that enables the achievement of these goals (pathway thinking) (Snyder et al., 1996). Hope could be said to be the ability to expect something with a high level of confidence (Bradshaw et al., 2015). These abilities can ultimately form a positive motivation to achieve the expected goals or success (Luthans et al., 2015). In other words, hope is very closely related to hard work or the persistence to achieve goals (Park, Peterson, \& Seligman, 2004). When an individual has high expectations, not only do they have the determination and motivation, but also the ability to achieve the expected success. Thus, this ability enables the individual to adapt by changing the way to achieve success (Sweetman et al., 2011). Based on these rationales, it could be said that higher hope could lead to more readiness for change.

H3: hope has a significant effect on readiness for change.

\section{Resilience and readiness for change}

Resilience can be defined as the individual's positive psychic ability in their efforts to rise again from difficulty, uncertainty, conflict, or even failure (Sweetman et al., 2011). This ability enables an individual to survive and make adjustment to changes (Surjantia et al, 2020). Resilience could make individuals feel more comfortable while being "outside [of their] comfort zone" (Robinson, Hanna, Raine, \& Robertson, 2017). Thus, individuals will feel more prepared to deal with any kind of consequences during the change process (Sweetman et al., 2011). Previous empirical studies also prove that resilience significantly affect readiness for change (Goksoy, 2012; Nwanzy \& Babalola, 2019). 
H4: resilience has a significant effect on readiness for change.

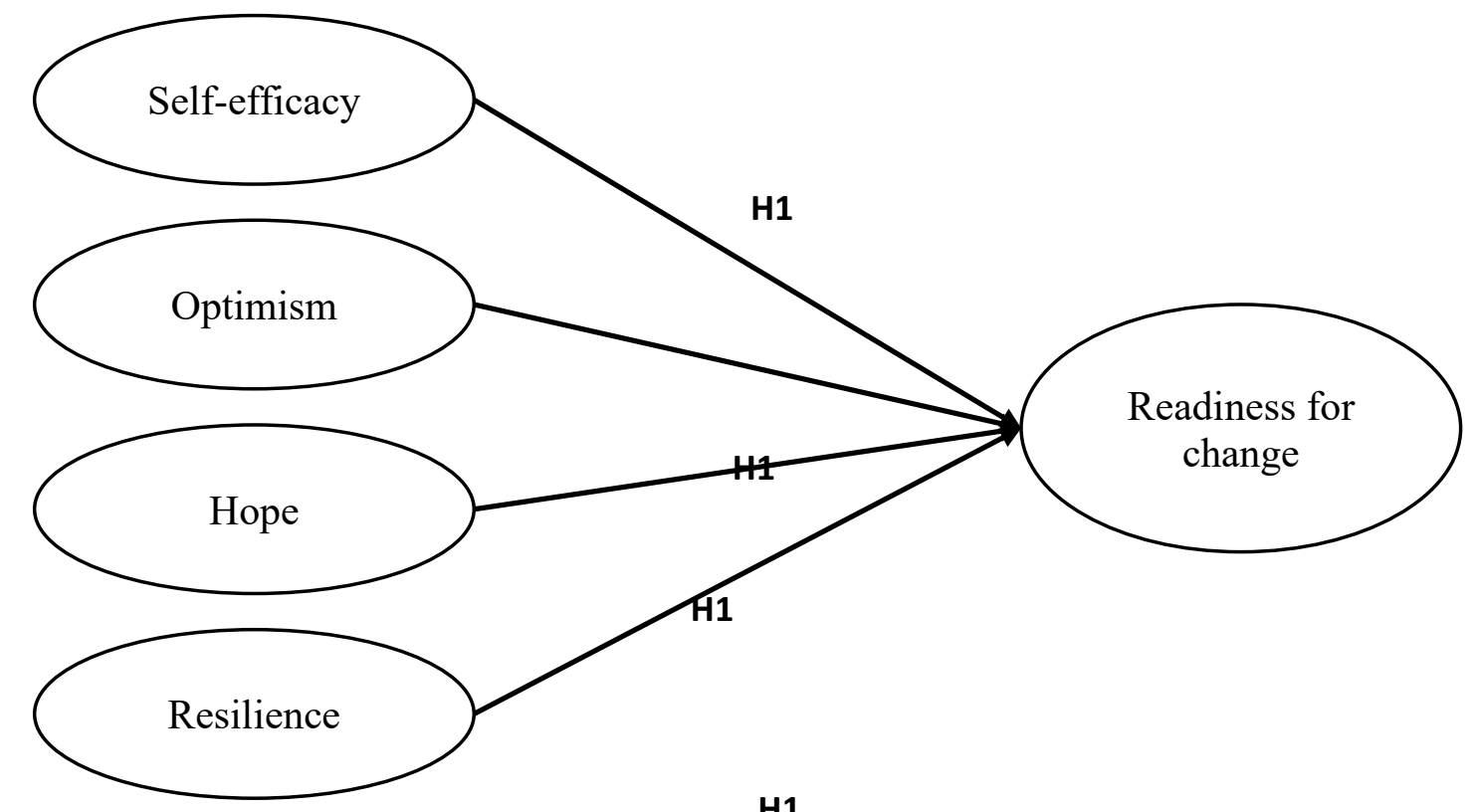

Figure 1. Research model

\section{METHODOLOGY}

This study is purposed to look for causal relationships between the variables studied. Thus, this is an explanatory quantitative study. The independent variables in this study are self-efficacy (X1); optimism (X2); hope (X3); and resilience (X4); while the dependent variable is readiness for change (Y). The measurement of the four PsyCap variables uses 24 indicators adopted from Luthans et al. (2007), which was contextually adjusted to the problems regarding the use of elearning in lecture activities by lecturers. Self-efficacy is measured using six (6) item indicators such as: "I feel confident analysing my misunderstanding problem in using e-learning to find a solution"; optimism is measured using six (6) item indicators such as: "I always look at the bright side of things regarding the lack of understanding about e-learning"; hope is measured with six (6) item statements such as: "there are lots of ways to solve my lack of understanding of e-learning"; resilience is measured using six (6) item statements such as: "I can get through difficult times learning e-learning because I've experienced difficulty before". Finally, for the measurement of readiness for change, adopted from Bouckenooghe et al. (2009), consisting of thirteen (13) item indicators such as: "I dedicate myself to the process of change" and "I experience the change as a positive process". All of the responses were measured using a Likert scale ranging from 1 as "strongly disagree", to 5 as "strongly agree". 
The data collection process was carried out from early March to the second week of April, 2020 (six weeks) with the target population being all lecturers in the East Java province of Indonesia, whose scope of educational institution is at the university level. The total number of lecturers referred within the population is unknown, due to the lack of a reliable reference that can be used as a reference for the population. Therefore, the minimum number of samples used refers to Hair, Sarstedt, Ringle and Mena (2012), which states that the minimum sample size required to process the data using Partial Least Square is ten times the maximum number of paths between latent variables. In this study there are four pathways that lead to the dependent variable. Thus, the minimum sample required is 40 respondents. Based on Hair et al. (2012), with the result of a minimum sample of 40 respondents, the questionnaires were distributed through a Google form format by sharing the link through a Whatsapp group and through email to lecturer colleagues. From a total of 79 respondents who filled out the questionnaires, eighteen (18) responses were eliminated due to being haphazardly filled. Thus, the total data that can be further processed is 61 respondents $(77.2 \%)$.

\section{RESULT}

The data processing in this study begins with the validity and reliability testing of the model with the help of SmartPLS 2.0 software, which was also used to test the research hypothesis. The first stage data processing can be seen in table 1, where the requirement to be considered as valid is the value of a loading factor which is greater than 0.5 , as the result indicates that in total ten (10) indicators did not meet the requirement. Thus, these indicators were dropped and not included in the next process.

Table 1. Loading factor stage 1

\begin{tabular}{|c|c|c|c|c|c|c|c|}
\hline \multicolumn{2}{|c|}{ Self-efficacy } & \multicolumn{2}{|c|}{ Optimism } & \multicolumn{2}{|c|}{ Hope } & \multicolumn{2}{|c|}{ Resilience } \\
\hline se1 & .8035 & op1 & .6943 & ho1 & .2219 & re1 & .7267 \\
\hline se2 & .8337 & op2 & .5218 & ho2 & .1468 & re2 & .6586 \\
\hline se3 & .8293 & op3 & .6047 & ho3 & .7585 & re3 & .7801 \\
\hline se4 & .6820 & op4 & .8027 & ho4 & .7974 & re4 & .7894 \\
\hline se 5 & .7491 & op5 & .6530 & ho5 & .7393 & re5 & .4775 \\
\hline se6 & .7426 & op6 & .7741 & ho6 & .6987 & re6 & .6890 \\
\hline \multicolumn{8}{|c|}{ Readiness for change } \\
\hline $\mathrm{rc} 1$ & .6643 & $\mathrm{rc5}$ & .7188 & rc9 & .1504 & rc13 & .1597 \\
\hline $\mathrm{rc} 2$ & .6847 & rc6 & .7713 & $\operatorname{rc10}$ & .0481 & & \\
\hline $\mathrm{rc} 3$ & .8387 & $\mathrm{rc} 7$ & .8159 & rc11 & .0972 & & \\
\hline $\mathrm{rc4}$ & .8435 & rc8 & -.0071 & $\mathbf{r c 1 2}$ & .3248 & & \\
\hline
\end{tabular}

After the dropping process in stage 1, the processing was continued by testing the loading factor for the second time. 


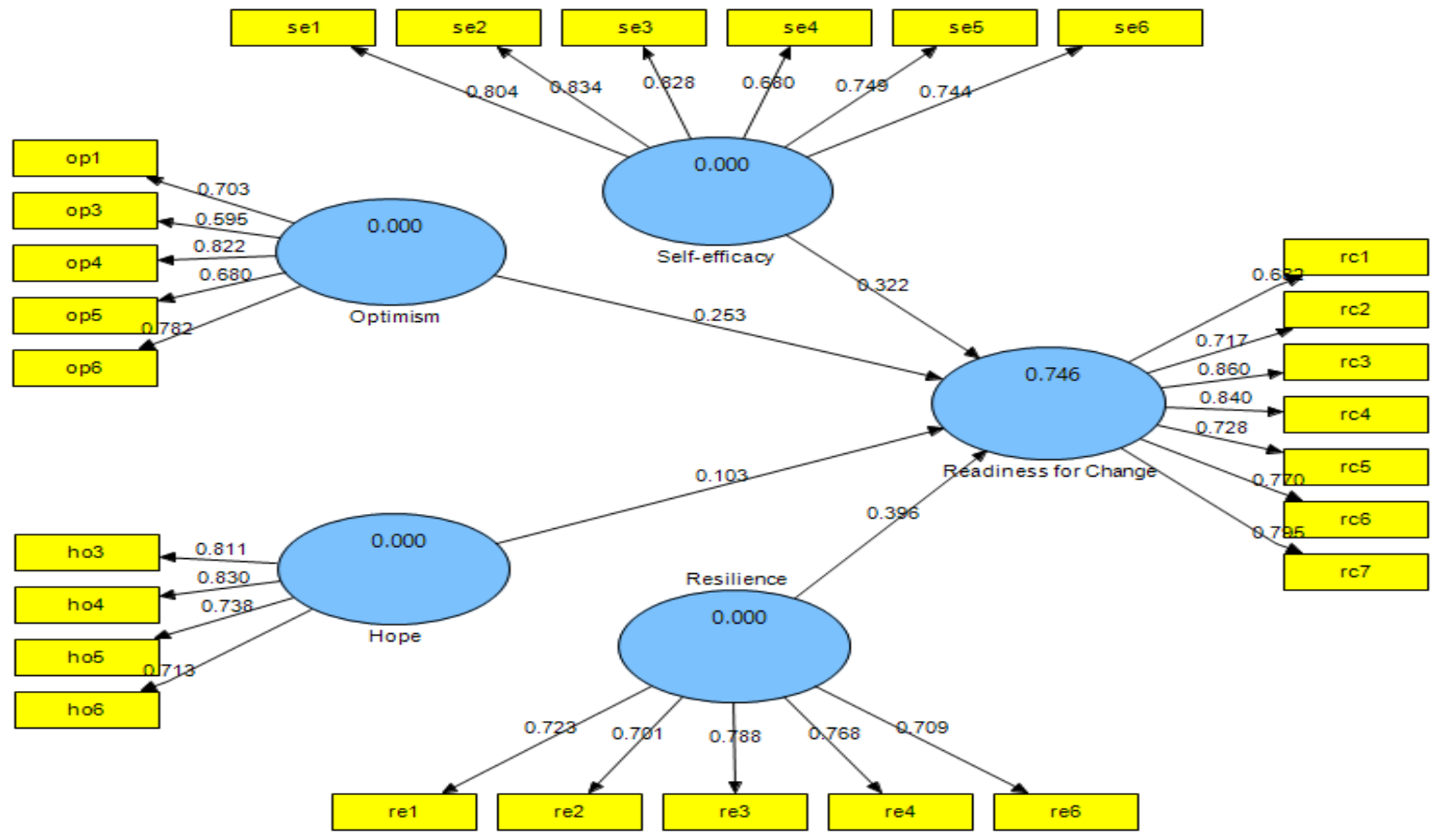

Figure 2. Path model and loading factor stage 2 (after dropping)

Based on figure 2, the result shows that all indicators have met the validity test requirement with the value of the loading factor greater than 0.5. It is found that indicators with the highest loading factor value in the self-efficacy variable are se2 (feel confident representing e-learning with students) with a value of 0.8337 , and se 3 (feel confident contributing to discussion about e-learning usage) with value of 0.8293 . The highest loading factor value for the optimism variable are op4 (optimistic about what will happen to me in the future regarding e-learning) with a value of 0.822 , and op6 (dealing with this e-learning problem, there must be a bright spot) with a value of 0.782 . For the hope variable, the highest loading factor values are ho3 (there are lots of ways to solve my lack of understanding of e-learning) with a value of 0.811 , and ho4 (quite successful learning about e-learning) with a value of 0.830 . For the resilience variable, the highest loading factor values are re3 (speak when I needed to about e-learning) with a value of 0.788 , and re4 (always put my stress in learning e-learning aside) with a value of 0.768. Finally, the highest loading factor for readiness for change variables are rc3 (the change is invigorating) with a value of 0.860 , and rc4 (not resistant to change) with a value of 0.840 .

The next test is to see the convergent validity and discriminant validity by comparing the AVE value with its cut-off value of 0.5 , and also comparing the AVE root value with its cut-off value which greater than 0.7. From table 2, it is found that the results meet the requirement of convergent validity and discriminant validity. As for the reliability test, to be considered as reliable the cut-off value of both composite and Cronbach Alpha should be greater than 0.7. 
International Journal of Innovation, Creativity and Change. www.ijicc.net

Volume 15, Issue 4, 2021

Based on table 2, it is indicated that the values are both higher than their cut-off value. Hence, all are considered as reliable.

Table 2. Validity and reliability test

\begin{tabular}{lcccc}
\hline & AVE & $\sqrt{ }$ AVE & $\begin{array}{c}\text { Composite } \\
\text { Reliability }\end{array}$ & $\begin{array}{c}\text { Cronbach } \\
\text { Alpha }\end{array}$ \\
\hline $\begin{array}{lccc}\text { Self-efficacy } \\
\text { Optimism }\end{array}$ & .6009 & .7752 & .8999 & .8663 \\
Hope & .5196 & .7208 & .8423 & .7729 \\
$\begin{array}{l}\text { Resilience } \\
\text { Readiness for }\end{array}$ & .5998 & .7745 & .8566 & .7781 \\
change & .5454 & .7385 & .8568 & .7990 \\
\hline
\end{tabular}

The final stage is to test the hypothesis by looking at the original sample value to determine the direction of the effect, which is then followed by looking at the T-statistic value to determine the significance and the resulting effect. The cut-off value for an effect to be considered as significant is if the T-statistic value indicates a value greater than 1.96. In the contrary, if the value is lower than 1.96 it can be concluded that the effect is not significant. Based on the result of the hypothesis test in table 3, it can be concluded that of the four proposed hypotheses, three of them were supported (hypothesis 1, 2, and 4), while the other hypothesis was not supported (hypothesis 3).

Table 3. Hypothesis testing

\begin{tabular}{lccc}
\hline & $\begin{array}{c}\text { Original } \\
\text { Sample }(\mathbf{O})\end{array}$ & $\begin{array}{c}\text { T Statistics } \\
(|\mathbf{O} / \mathbf{S T E R R}|)\end{array}$ & Hypothesis \\
\hline Self-efficacy -> Readiness for change & .3222 & 2.7805 & Supported \\
Optimism -> Readiness for change & .2526 & 4.1673 & Supported \\
Hope -> Readiness for change & .1027 & 1.4285 & Not supported \\
Resilience -> Readiness for change & .3958 & 4.2565 & Supported \\
\hline
\end{tabular}

\section{DISCUSSION}

Partially, three out of four dimensions of PsyCap affect the enhancement of readiness for change. Firstly, the higher self-efficacy will increase the readiness for change. This result supports the previous study by Nwanzu and Babalola (2019) and Emsza et al. (2016), who argue that an individual's self-confidence could influence the perception of feeling confident regarding the change initiatives to successfully achieve the planned goals. In this current study context, self-efficacy is reflected by the indicator "I feel confident in representing e-learning with students". When lecturers feel that they have high self-confidence, the level of confidence will arise to feel ready to initiate changes, following the current condition which is conducting 
lectures through e-learning. Hence, self-confidence is considered one of the important factors needed to be prepared to make changes.

Secondly, it is concluded that the higher optimism will increase the readiness for change. This result supports the previous study by Wanberg and Banas (2000) and Nwanzu and Babalola (2019). Optimistic individuals tend not to experience stress quickly, especially when facing difficulties and when those individuals are faced with a change process that must be gone through. These individuals should have this kind of confidence to be able to successfully challenge the change process in order to be better prepared to change (Aspinwall et al., 2004; Peterson \& De Avila, 1995). In this current study context, optimism is reflected through the indicator "I'm optimistic about what will happen to me in the future regarding e-learning". Optimistic lecturers will tend to believe that their efforts toward learn e-learning will produce positive results, which helps make them feel more prepared to change.

Thirdly, it is concluded that the higher resilience effort will lead to greater readiness for change. This result also supports the previous studies by Goksoy (2012) and Nwanzu and Babalola (2019). Individuals with higher resilience will feel more prepared during being outside of the "comfort zone", while in order to implement change initiatives, this resilience will affect the feeling of being prepared to deal with all the consequences that might be experienced (Robinson et al., 2017; Sweetman et al., 2011). In the context of lecturers, resilience is reflected through the indicator "I can be myself to speak when I need to about e-learning". Thus, as long as the lecturers are always being themselves when learning more about their problems, especially in e-learning, and seeing from within the positive perspective of what is being done, they will be able to further enhance their resilience to be more prepared to initiate changes.

Furthermore, as explained earlier, one out of the four hypotheses proposed is not supported, namely the role of hope on readiness for change. Although it has a positive impact, nonetheless this study has not been able to explain the role of hope in enhancing readiness for change. Thus, this result is not in line with the previous study by Sweetman et al. (2011). Hope is one of the PsyCap dimensions that is the least researched by academics, even nearly neglected (Cohen, 2015; Feldman \& Kubota, 2015). Apart from the lack of empirical evidence that focuses on hope factors, the argument that could be proposed is that hope is more likely to have a prominent impact related to things that are personal and often associated with so called "life and death" situations (Cohen, 2015; Nesse, 1999). In the context of this research, readiness for change within the university environment, it is not related, regardless of being ready or not ready to initiate changes. The condition is far simpler and not a complicated one for lecturers. The role of hope in the present study's context might be different when it is associated with "religious factors", as a form of a calling through education (Holloway, 2012; Marques, Lopez, \& Mitchell, 2012).

One finding that is considered interesting in the context of lecturers' readiness for change to undertake e-learning is the indicator "I find the change invigorating" as dominantly reflecting 
readiness for change. Within the lecturer context, it is considered that change for lecturers is actually a positive thing and also gives enthusiasm for change. Teaching is also considered a "calling to serve" (Bullough \& Hall-Kenyon, 2012). Hence, the challenges that might come should not be avoided but instead be faced. This kind of "calling" also implies a deep conviction that teaching is considered a real implication of action representing the awareness to serve.

\section{CONCLUSION}

This study emphasises the role of PsyCap's dimensions on readiness for change in the context of university lecturers in Indonesia, especially in the East Java province. It is concluded that self-efficacy has a significant effect on readiness for change, optimism has a significant effect on readiness for change, and resilience has a significant effect on readiness for change, while hope has no significant effect on readiness for change. Suggestions for further study are firstly, to conduct additional study focusing on the impact on readiness for change, especially related to the antecedent factors of PsyCap which need to be further developed in the Indonesian context, specifically in the education context. Secondly, it is suggested that additional empirical study be conducted related to the role of hope in supporting readiness for change, with the intervention of "religious factors", such as morality or faith. 
International Journal of Innovation, Creativity and Change. www.ijicc.net

Volume 15, Issue 4, 2021

\section{REFERENCES}

Ahmad, S. A., Yoke, S. K., Yunos, R. M., \& Amin, J. M. (2019). Exploring lecturers' readiness for 21st century education in Malaysian higher learning institutions. European Journal of Teaching and Education, 1(1), 15-29. https://doi.org/10.33422/ejte.2019.10.27

Alhefnawi, M.A.M., Dano, U.L., Istanbouli, M. J., Al-Gehlani, W.A.G., Afify, H.M.N., \& Rahaal, M.S. (2021). Exam Grades in Architecture Classes: A Comparative Assessment of Before and During COVID-19 Pandemic Modes of Teaching and Learning, International Journal of Innovation, Creativity and Change, 15(2), 54-68

Al-Rabiaah, A., Temsah, M. H., Al-Eyadhy, A. A., Hasan, G. M., Al-Zamil, F., Al-Subaie, S., ... Somily, A. M. (2020). Middle East Respiratory Syndrome-Corona Virus (MERS$\mathrm{CoV}$ ) associated stress among medical students at a university teaching hospital in Saudi Arabia. Journal of Infection and Public Health. https://doi.org/10.1016/j.jiph.2020.01.005

Aspinwall, L. G., Richter, L., \& Hoffman, R. R. (2004). Understanding how optimism works: An examination of optimists' adaptive moderation of belief and behaviour. In Optimism \& pessimism: Implications for theory, research, and practice. (pp. 217-238). https://doi.org/10.1037/10385-010

Avey, J. B., Wernsing, T. S., \& Luthans, F. (2008). Can positive employees help positive organisational change?: Impact of psychological capital and emotions on relevant attitudes and behaviours. Journal of Applied Behavioural Science, 44(1), 48-70. https://doi.org/10.1177/0021886307311470

Berliyanto, \& Santoso, H. B. (2018). Indonesian perspective on massive open online courses: Opportunities and challenges. Journal of Educators Online, 15(1). https://doi.org/10.9743/jeo2018.15.1.11

Bouckenooghe, D., Devos, G., \& Van Den Broeck, H. (2009). Organisational change questionnaire-climate of change, processes, and readiness: Development of a new instrument. Journal of Psychology: Interdisciplinary and Applied, 143(6), 559-599. https://doi.org/10.1080/00223980903218216

Bradshaw, S., Shumway, S. T., Wang, E. W., Harris, K. S., Smith, D. B., \& Austin-Robillard, H. (2015). Hope, readiness, and coping in family recovery from addiction. Journal of Groups in Addiction and Recovery, 10(4), 313-336. https://doi.org/10.1080/1556035X.2015.1099125

Bullough, R. V. J., \& Hall-Kenyon, K. M. (2012). On teacher hope, sense of calling, and commitment to teaching. Teacher Education Quarterly, 39(2), 7-27. Retrieved from http://eric.ed.gov/?id=EJ989781

Çavuş, M. F., \& Gökçen, A. (2015). Psychological capital: Definition, components and effects. British Journal of Education, Society \& Behavioural Science, 5(3), 244-255. https://doi.org/10.9734/bjesbs/2015/12574

Çetin, F. (2011). The effects of the organisational psychological capital on the attitudes of commitment and satisfaction: A public sample in Turkey. European Journal of Social Sciences, 21(3), 373-380. 
International Journal of Innovation, Creativity and Change. www.ijicc.net Volume 15, Issue 4, 2021

Cohen, V. (2015). "Hope Dies Last." In The Critical Pulse (pp. 129-134). https://doi.org/10.7312/columbia/9780231161152.003.0018

Crossley, S. A., \& McNamara, D. S. (2016). Adaptive educational technologies for literacy instruction. In Adaptive Educational Technologies for Literacy Instruction (pp. 1-310). https://doi.org/10.4324/9781315647500

Darling-Hammond, L., Flook, L., Cook-Harvey, C., Barron, B., \& Osher, D. (2020). Implications for educational practice of the science of learning and development. Applied Developmental Science, 24(2). https://doi.org/10.1080/10888691.2018.1537791

Emsza, B., Eliyana, A., \& Istyarini, W. (2016). The relationship between self efficacy and readiness for change: The mediator roles of employee empowerment. Mediterranean Journal of Social Sciences. https://doi.org/10.5901/mjss.2016.v7n3s1p201

Fachruddin, D. F., \& Mangundjaya, W. H. (2012). The impact of workplace well-being and psychological capital, to the Individual readiness for change. In Proceedings 4th Asian Psychological Association (Vol. 66, pp. 37-39).

Feldman, D. B., \& Kubota, M. (2015). Hope, self-efficacy, optimism, and academic achievement: Distinguishing constructs and levels of specificity in predicting college grade-point average. Learning and Individual Differences, 37, 210-216. https://doi.org/10.1016/j.lindif.2014.11.022

Fredrickson, B. L. (2001). The role of positive emotions in positive psychology: The broadenand-build theory of positive emotions. American Psychologist, 56(3), 218-226. https://doi.org/10.1037/0003-066X.56.3.218

Gangloff, B., \& Mazilescu, C. A. (2017). Normative characteristics of perceived self-efficacy. Social Sciences, 6(4). https://doi.org/10.3390/socsci6040139

Goksoy, A. (2012). The impact of job insecurity, role ambiguity, self monitoring and perceived fairness of previous change on individual readiness for change. Journal of Global Strategic Management, 1(6), 102-102. https://doi.org/10.20460/jgsm.2012615790

Hafeez, M., Ajmal, F., \& Kazmi, Q.A. (2021). Challenges faced by the teachers and students in online learning. International Journal of Innovation, Creativity and Change, 15(2), 325-346

Hair, J. F., Sarstedt, M., Ringle, C. M., \& Mena, J. A. (2012). An assessment of the use of partial least squares structural equation modeling in marketing research. Journal of the Academy of Marketing Science, 40(3), 414-433. https://doi.org/10.1007/s11747-0110261-6

Holloway, C. C. (2012). Teaching as a calling. Becoming a Win-Win Teacher: Survival Strategies for the Beginning Educator Becoming a Win-Win Teacher: Survival Strategies for the Beginning Educator, 83(2), 12-17. https://doi.org/10.4135/9781452219035.n3

Islam, N., Beer, M., \& Slack, F. (2015). E-Learning challenges faced by academics in higher education: A literature review. Journal of Education and Training Studies, 3(5). https://doi.org/10.11114/jets.v3i5.947

Kebritchi, M., Lipschuetz, A., \& Santiague, L. (2017). Issues and challenges for teaching successful online courses in higher education. Journal of Educational Technology 
International Journal of Innovation, Creativity and Change. www.ijicc.net Volume 15, Issue 4, 2021

Systems, 46(1), 4-29. https://doi.org/10.1177/0047239516661713

Kirrane, M., Lennon, M., O'Connor, C., \& Fu, N. (2017). Linking perceived management support with employees' readiness for change: the mediating role of psychological capital. Journal of Change Management, 17(1), 47-66. https://doi.org/10.1080/14697017.2016.1214615

Lee, K. (2020). Coronavirus: Universities are shifting classes online - but it's not as easy as it sounds. Retrieved April 15, 2020, from https://theconversation.com/coronavirusuniversities-are-shifting-classes-online-but-its-not-as-easy-as-it-sounds-133030

Liwarto, I., \& Kurniawan, A. (2015). The relationship between psycap and employee performance PT. X Bandung. Jurnal Manajemen Maranatha, 14(2), 115053. https://doi.org/10.28932/jmm.v14i2.36

Lizar, A. A., Mangundjaya, W. L. ., \& Rachmawan, A. (2015). The role of psychological capital and psychological empowerment on individual readiness for change. The Journal of Developing Areas, 49(5), 343-352. https://doi.org/10.1353/jda.2015.0063

Luthans, F., \& Avolio, B. J. (2009). The "Point" of positive organisational behaviour. Journal of Organisational Behaviour, 30(2), 291-307. https://doi.org/10.1002/job.589

Luthans, F., Youssef-Morgan, C. M., \& Avolio, B. J. (2015). Psychological capital and beyond (1st ed.). New York: Oxford University Press.

Luthans, F., Youssef, C. M., \& Avolio, B. J. (2007). Psychological capital: Developing the human competitive edge. Psychological Capital: Developing the Human Competitive Edge (1st ed.). New York: Oxford University Press. https://doi.org/10.1093/acprof:oso/9780195187526.001.0001

Marques, S. C., Lopez, S. J., \& Mitchell, J. (2012). The role of hope, spirituality and religious practice in adolescents' life satisfaction: Longitudinal findings. Journal of Happiness Studies, 14(1), 251-261. https://doi.org/10.1007/s10902-012-9329-3

Ministry of Education and Culture of the Republic of Indonesia. (2020). Ministry of education and culture issues SE on the education implementation during Covid-19 emergency period. $\quad$ Retrieved April 17, 2020, from https://www.kemdikbud.go.id/main/blog/2016/05/rumah-kunci-sukses-pola-asuh-anak

Mishra, P., \& Koehler, M. J. (2006). Technological pedagogical content knowledge: A framework for teacher knowledge. Teachers College Record, 108(6), 1017-1054. https://doi.org/10.1111/j.1467-9620.2006.00684.x

Mutia, I., \& Leonard. (2015). Study of the implementation of e-learning in higher education learning process. Faktor Exacta, 6(4), 278-289.

Nesse, R. M. (1999). The evolution of hope and despair. Social Research, 66(2), 1-469.

Nugroho, D. A. S., Mujiasih, E., \& Prihatsanti, U. (2013). The relationship between psychological capital and employees' work engagement in PT. Bank Mega Regional Area Semarang. Jurnal Psikologi, 12(2), 192-202. https://doi.org/10.14710/jpu.12.2.192-202

Nwanzu, C. L., \& Babalola, S. S. (2019). Examining psychological capital of optimism, selfefficacy and self-monitoring as predictors of attitude towards organisational change. International Journal of Engineering Business Management, 11. 
International Journal of Innovation, Creativity and Change. www.ijicc.net

Volume 15, Issue 4, 2021

https://doi.org/10.1177/1847979019827149

Pachura, A. (2017). Innovation and change in networked reality. Polish Journal of Management Studies, 15(2), 173-182.

Park, N., Peterson, C., \& Seligman, M. E. P. (2004). Strengths of character and well-being. Journal of Social and Clinical Psychology, 23(5), 603-619. https://doi.org/10.1521/jscp.23.5.603.50748

Perbawaningsih, Y. (2013). Plus minus of ICT usage in higher education students. Procedia $\begin{array}{llll}\text { Social and Behavioural } & \text { Sciences, }\end{array}$ https://doi.org/10.1016/j.sbspro.2013.10.392

Peterson, C., \& De Avila, M. E. (1995). Optimistic explanatory style and the perception of health problems. Journal of Clinical Psychology, 51(1), 128-132. https://doi.org/10.1002/1097-4679(199501)51:1<128::AID-

JCLP2270510120>3.0.CO;2-1

Robinson, M., Hanna, E., Raine, G., \& Robertson, S. (2017). Extending the comfort zone: Building resilience in older people with long-term conditions. Journal of Applied Gerontology, 38(6), 825-848. https://doi.org/10.1177/0733464817724042

Sahu, P. (2020). Closure of universities due to Coronavirus disease 2019 (COVID-19): Impact on education and mental health of students and academic staff. Cureus, 12(4). https://doi.org/10.7759/cureus.7541

Shea, C. M., Jacobs, S. R., Esserman, D. A., Bruce, K., \& Weiner, B. J. (2014). Organisational readiness for implementing change: A psychometric assessment of a new measure. Implementation Science, 9(1). https://doi.org/10.1186/1748-5908-9-7

Snyder, C. R., Sympson, S. C., Ybasco, F. C., Borders, T. F., Babyak, M. A., \& Higgins, R. L. (1996). Development and validation of the state hope scale. Journal of Personality and Social Psychology, 70(2), 321-335. https://doi.org/10.1037/0022-3514.70.2.321

Sun, A., \& Chen, X. (2016). Online education and its effective practice: A research review. Journal of Information Technology Education: Research, 15(2016), 157-190. https://doi.org/10.28945/3502

Surjantia, J., Saktib, N.C., \& Fitrayati, D. (2020). Virtual-Based Learning Attitude: The Mediator of Individual Factors on Intention to Use International Journal of Innovation, Creativity and Change, 12(4), 165-186

Sweetman, D., Luthans, F., Avey, J. B., \& Luthans, B. C. (2011). Relationship between positive psychological capital and creative performance. Canadian Journal of Administrative Sciences, 28(1), 4-13. https://doi.org/10.1002/cjas.175

Vakola, M. (2013). Multilevel readiness to organisational change: A conceptual approach. Journal of Change Management, 13(1), 96-109. https://doi.org/10.1080/14697017.2013.768436

Vakola, M. (2014). What's in there for me? Individual readiness to change and the perceived impact of organisational change. Leadership and Organisation Development Journal, 35(3), 195-209. https://doi.org/10.1108/LODJ-05-2012-0064 
Wanberg, C. R., \& Banas, J. T. (2000). Predictors and outcomes of openness to changes in a reorganising workplace. Journal of Applied Psychology, 85(1), 132-142. https://doi.org/10.1037/0021-9010.85.1.132

Weiner, B. J. (2009). A theory of organisational readiness for change. Implementation Science, 4(1). https://doi.org/10.1186/1748-5908-4-67

WHO. (2020). Coronavirus disease 2019 (COVID-19) situation report. World Health Organisation (Vol. 85). https://doi.org/10.1001/jama.2020.2633

Widianto, S., \& Wilderom, C. P. M. (2017). Transformational leadership, service climate, psychological capital and job performance/engagement. Academy of Management Proceedings, 2017(1), 10318. https://doi.org/10.5465/ambpp.2017.10318abstract

Youssef-Morgan, C. M., \& Luthans, F. (2015). Psychological capital and well-being. Stress and Health, 31(3), 180-188. https://doi.org/10.1002/smi.2623 